\title{
New procedures with new activity assumptions for solving resource con- strained project scheduling problems
}

\author{
Samer Ben Issa ${ }^{a^{*}}$ and Yiliu Tu ${ }^{a}$
}

${ }^{a}$ Schulich School of Engineering, Department of Mechanical and Manufacturing Engineering, University Drive 2500, N.W., Calgary, Alberta T2N 1N4, Canada

\section{H R O N I C L E}

Article history:

Received: May 252019

Received in revised format: June

212019

Accepted: July 212019

Available online:

July 222019

Keywords:

Project scheduling

Limited multi-resource

$A B C D$ activity classifications

Flexible resource profile

\begin{abstract}
A B S T R A C T
The resource-constrained project scheduling problem (RCPSP) is a well-known and widely studied topic. The underlying problem assumes that non-preemptions and that constant resources are restrictions imposed on project activities, which are to be scheduled, subject to precedence relation and limited resource constraints. Project activities, in RCPSP, are classified under category A. The problem is expanded to include various other activity assumptions categories, such as B and C. In the Preemptive-RCPSP, project activities are classified under category $\mathrm{B}$, which refers to the activity that can be implemented using constant resources and constant durations. In the Flexible-RCPSP, project activities are classified under category $\mathrm{C}$, which refers to the activities that can be executed using flexible resources over flexible durations, and preemptions are not allowed. However, in One-of-a-Kind Production companies (OKP), such as the housing industry, plastic injection moldings, and RV manufacturing, all known as "manufactured-to-order" operations, the activities are classified under category D in addition to A, B, and C, simultaneously. Category D refers to the activities that can be executed using flexible durations and flexible resources, and preemptions are allowed. In this paper, therefore, we present a new effective model in order to deal with the projects that consist of all the previous activity assumptions simultaneously to generate feasible project schedules. Case studies are included, and the results show that the resources usage is increased and the project makespan is reduced.
\end{abstract}

C 2020 by the authors; licensee Growing Science, Canada.

\section{Introduction}

In the context of Project Scheduling (PS), one of the most widely studied problems is the ResourceConstrained Project Scheduling Problem (RCPSP). In an Activity-on-Node (AON) format, $N$ is a set of nodes used to represent the $n$ activities, and a set of pairs of activities $A$ represents the precedence relations between activities (i.e., finish to start relations with a minimal time-lag of zero). In the RCPSP, activities are assumed to have constant durations, constant resources, and preemptions are not allowed. The decision variables are the starting of activities times when the resource availabilities are considered as given. The activities can be performed in only one possible execution mode, and the resources are assumed to be available in a constant amount for each time.

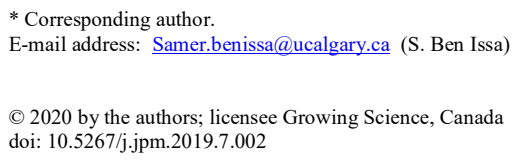


Moreover, each activity demands a constant amount of resources during the execution. The objective of the RCPSP is to obtain a feasible schedule that meets the constraints in a way so as to minimize project makespan. The RCPSP, the subject of much attention, have been well-documented. Kolisch and Hartmann 1999, 2006; Hartmann and Kolisch 2000; Hartmann and Briskorn 2010; Zhang, Li, and Tam 2006; and Fang and Wang 2012 presented many works of literature used the exact method and heuristics method to solve the RCPSP.

In this paper, we classify the problem to four types based on the activity categories as follows. First, when project activities are classified under category A, (i.e., activities can be executed using constant resource over constant duration, and cannot be interrupted, as depicted in Fig. 1) the problem so-called "Resource-Constrained Project Scheduling Problem" (RCPSP or RCPSP $($ A) $)$. Second, when project activities under category B, (i.e., activities can be executed using the same character of resource and duration as A, but activities can be interrupted, as displayed in Fig. 2), the problem so-called "Preemptive Resource-Constrained Project Scheduling Problem" (P-RCPSP or RCPSP ). Third, when project activities are classified under category $C$ (i.e., activities can be executed using flexible resource over flexible duration and cannot be interrupted, as shown in Fig. 3) the problem so-called "Flexible Resource Constrained Project Scheduling Problem" (F-RCPSP or RCPSP ${ }_{(\mathrm{C})}$ ). Fourth, when project activities are classified under category D (i.e., activities have the same character of resource and duration as C, but they can be interrupted, as depicted in Fig. 4) the problem so-called "Flexible Preemptive Resource -Constrained Project Scheduling Problem" (F-P-RCPSP or $\left.\operatorname{RCPSP}_{(\mathrm{D})}\right)$.

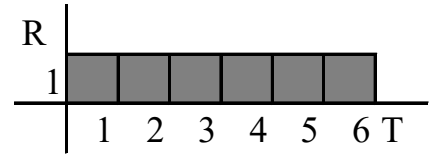

Fig. 1. Activity under category A ( $\left.\operatorname{RCPSP}_{(\mathrm{A})}\right)$.

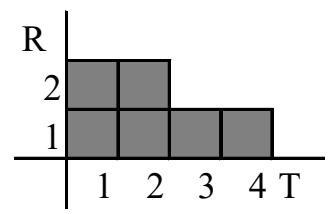

Fig. 3. activity under category $\mathrm{C}\left(\mathrm{RCPSP}_{(\mathrm{C})}\right)$.

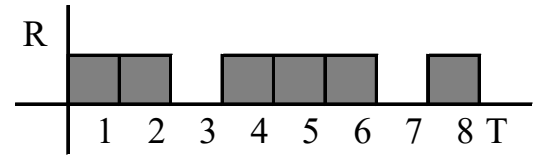

Fig. 2. Activity under category $\mathrm{B}\left(\mathrm{RCPSP}_{(\mathrm{B})}\right)$

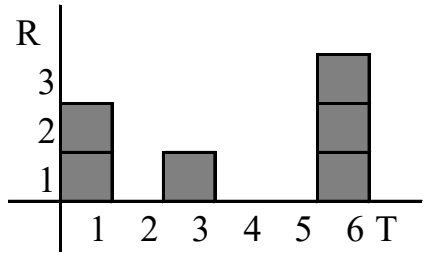

Fig. 4. Activity under category D ( $\left.\operatorname{RCPSP}_{(\mathrm{D})}\right)$

Table 1 below summarizes the important activity assumptions implemented in different types of RCPSP. In the RCPSP, project activities are classified under category A. In the Preemptive Resource-Constrained Project Scheduling Problems (P-RCBSP), project activities are categorized under category B. In the Flexible Resource-Constrained Project Scheduling Problems (F-RCPSP) project activities under category C. In the P-F-RCPSP, when the project activities can be preemptable, and resources can be flexible, project activities are classified under category D. Equally important, in most software packages, the activities under category A has been considered as inputs. Whereas category $\mathrm{B}$ and $\mathrm{C}$ assumptions have never been considered, and if any, they can be made by the user before creating a feasible resource schedule. Activities such as welding activity, cutting activity, or assembly activity can be accelerated its execution by increasing the resources. To the best of our knowledge, these types of activities are classified under category $\mathrm{B}$ or $\mathrm{C}$ in most of the previous literature, if not all.

Table 1

The activity assumptions implemented in different types of basic RCPSPs

\begin{tabular}{|c|c|c|c|c|c|c|}
\hline General & Activity Categories & Constant Duration & Constant Rresource & Flexible Resources & Interruption & State \\
\hline RCPSP & $\mathrm{A}$ & $\checkmark$ & $\checkmark$ & $\mathrm{x}$ & $\mathrm{x}$ & Used \\
\hline P-RCPSP & B & $\checkmark$ & $\checkmark$ & $\mathrm{x}$ & $\checkmark$ & Used \\
\hline F-RCPSP & $\mathrm{C}$ & $\mathrm{x}$ & $\mathrm{x}$ & $\checkmark$ & $\mathrm{x}$ & Used \\
\hline P-F-RCPSP & D & $\mathrm{x}$ & $\mathrm{x}$ & $\checkmark$ & $\checkmark$ & New \\
\hline
\end{tabular}


However, the problem is: researchers have classified the project activities individually under categories A, B, or C (e.g., Peteghem \& Vanhoucke 2010; Kellenbrink \& Helber 2015). But in practice, the F-RCPSP can be enforced in the P-F-RCPSP as a special case by allowing the activity to be preempted. Put another way, category $\mathrm{C}$ can be covered by category $\mathrm{D}$. As a result, from a preemptive perspective, we simultaneously represent the problem related to the three types of activity assumptions, A, B, and D. To sum up, we identified the extensions of RCPSP as Resource-Constrained Project Scheduling Problem under A, B, and C activity assumptions $\left(\mathrm{RCPSP}_{(\mathrm{ABD})}\right)$. The contributions of this paper are as follows: 1) Presenting a new algorithm to solve general and real cases of RCPSP when project activities are considered under (A, B, and D) simultaneously. 2) generating several schedules for various projects, which modified from PSPLIB, and measuring the impact of the activity assumptions on the project duration, resource utilization, and the percentage of the project duration improvement.

\section{Litereture review}

Besides no paper has handled hundreds of activities in reasonable computation time; all the literature described activities less than one hundred (Peteghem \& Vanhoucke 2014). Accordingly, the previous literature has only dealt with projects having activities under category A, B, or C, each treated individually. Peteghem and Vanhoucke (2010) introduce a Genetic algorithm (GA) for solving the MRCPSP and Preemptive Multi-Resource Constrained Project Scheduling Problems (PMRCPSPs). The MRCPSP is a generalized version of RCPSP, where each activity can be executed in one out of a set of modes, which allows the project activities to be under category B. Fundeling and Trautmann (2010) have considered a Project Scheduling Problem (PSP) in which the activities are characterized by work-content (PSPWC). That is, the resources allocated to an activity usually may vary over time subject to some restrictions. This means that the project activities are classified under category C. Ranjbar and Kianfar (2010) proposed a procedure to find all feasible work profile for each activity and used GA with a new crossover operator to schedule the project activities, the activities can not be preempted during the execution (i.e., activities are classified under category C). Bianco and Caramia (2013) proposed a new formulation for RCPSP with finish-to-start constraints, pre-emption is not allowed, scarce resources and minimum makespan objective. Project activities in this paper considered under category A. Colak et al. (2013) consider the Multi-Mode Resource Constrained Project Scheduling Problem with Renewable Resources (MRCPSP-RR), where each activity can be executed in one of the possible modes, i.e., different durations and different resources. Minimum Latest Start Time (Min-LST), Shortest Feasible Mode with Conditional Wait for the Fastest Mode (SFM-CWFM), and Shortest Feasible Mode with Conditional Wait for the Better Mode (SFM-CWBM) are heuristics, which do not use in MRCPSP-RR before for activity selection. The activities are considered under category A. Baumann and Trautmann (2013) formulated the RCPSP as a Mixed Linear Program (MLP) for small instances, and the activities have been considered under category C. Naber and Kolisch (2014) proposed four model formulations for the F-RCPSP and compared their model efficiency in terms of solution quality and computational times. Peteghem and Vanhoucke (2014) present an overview of the existing meta-heuristic for solving MRCPSP. The MRCPSP aims to find a mode and a start time for each activity to schedule the project within the minimal makespan. The research paper considers only renewable resources, and the problem has been referred to as MRCPSP/R. All the activities in this paper are under category A. Cheng et al. (2015) illustrate the difference between the preemption and activity splitting in the RCPSP as follows: P1 represents the RCPSPs without activity splitting, P2 represents the RCPSPs with non-preemptive activity splitting, and P3 represents the P-RCPSP. In this paper, project activities considered under Category B. Ma et al. (2016) address the Uncertain Resource-Constrained Project Scheduling Problem (URCPSP). The start and finish times and resource usage in most literature about the RCPSP are given in advanced for each activity. This implies the activities are under category A. Issa and Tu (2017) develop the branch and bound (B\&B) heuristic to solve the RCPSP. They use the splitting activity as a way to cut down the project makespan. The activities are classified under category B. Elsayed et al. (2017) present a Consolidated Optimization 
algorithm (COA) which has more one optimization algorithm, each of which uses two multi-operator algorithms (MOAs) to solve the RCPSP. The activities in this paper are under category A. Oztemel and Selam (2017) use a new meta-heuristic to select an effective single mode for MRCPSP. Bee Colony Optimization (BCO) approach has been used to complete the project on time. the activities are considered under category A. Naber (2017) proposes a MIP model that uses the continuous-time system to synchronize resources and activities where each activity may start, end, or change its resource allocation at any point of time. Tritschler et al. (2017) propose a Hybrid Metaheuristic (HM) by transferring resource quantities between selected activities as a way to improve project schedules in a variable neighborhood search. Afshar-Nadjafi (2018) extends the MRCPSP to the Preemptive Multi-mode Resource Constrained Project Scheduling Problem with permitted Mode Change (P-MRCPSP-MC) after preemption. This model is not considered in the past literature. Fixed work content is given for each project activities instead of a fixed duration and known resource requirements. Renewable and non-renewable resource types have been used in the problem. The accomplishing time of an activity can be interrupted at discrete time instances and restarted later with the same or different mode. The activities are considered under category B. Tao et al. (2018) propose an extension of MRCPSP when the project network can be selected according to specific rules. The project does not have a fixed network diagram for its execution. In real-world applications, project structure is variant and how to choose project structure is a significant decision for the scheduling problem. Project activities in this paper are under Category A. Vanhoucke and Coelho (2018) present an overview of the state-of-art algorithms for RCPSP and MRCPSP. The paper aims at demonstrating that most algorithms are still not able to solve instances much bigger in size than the ones presented between (1995-2017) or cannot solve problems with a different network and/or resource structure than usually used in the academic literature. The main goal of the paper is to provide a way to present best solutions obtained from the best performing procedure in literature and to set up a system for uploading solutions for alternative project data like PSPLIB and MMLIB uploading system. Project activities are considered under category A. Table 2 represents the glossary of symbols used in the present published papers, and Table 3 highlights the classification of project activities under different types of activity categories:

Table 2

Glossary of symbols

\begin{tabular}{ll}
\hline ACE-SP & Agarwal, Colak, and Erenguc-Single Pass. \\
B\&B & Branch and Bound \\
BCO & Bee Colony Optimization \\
BPGA & Bi-Population Genetic Algorithm. \\
COA & Consolidated Optimization Algorithm \\
FRCPSP & Flexible-Resource-constrained Project Scheduling Problem \\
GA & Genetic algorithm \\
\hline HM-GA-VNS & hybrid meta-heuristic with Genetic Algorithm combined with a variable neighborhood search \\
MILP & Mixed Integer Linear Program \\
MRCPSP & Multi-mode Resource-constrained Project Scheduling Problem. \\
MRCPSP-APS & Multi-Resource-Constrained Project Scheduling Problem with Alternative Project Structure \\
MRCPSP-RR & Multi-mode Resource Constrained Project Scheduling Problem with Renewable Resource. \\
PR & Priority Rules \\
P-MRCPSP & Preemptive-Multi-mode Resource-constrained Project Scheduling Problem. \\
P-MRCPSP-MC & Preemptive Multi-mode Resource Constrained Project Scheduling Problem with permitted Mode Change \\
PSPWC & Project Scheduling Problem Work-Content \\
RCPSP-FWP & Resource-Constrained Project Scheduling Problem- Flexible Work Profile \\
SA & Simulated Annealing \\
URCPSP & Uncertain Resource-Constrained Project Scheduling Problem \\
TS & Tabu Search. \\
\hline
\end{tabular}

The project scheduling problem addressed in this paper is extended to cover a much fuller range of engineering project requirements, and it then gives project managers more flexibility for planning and scheduling projects. However, for all these research papers, the classification of projects' activities to A, B, and D was not mentioned nor was not dealt with previously. The remainder of this paper is organized as follows. Section 3 addresses the problem description. Section 4 illustrates the proposed module. Section 5 presents a numerical example. Section 6 provides the computational results. Section 7 gives a conclusion. 
Table 3

A summary about the RCPSP and RCMPSP for the papers mentioned in this paper (2010-2018)

\begin{tabular}{|c|c|c|c|c|c|c|c|c|c|}
\hline & Author & Year & Type of the prob. & Method & Dataset & $\mathbf{A}$ & B & $\mathrm{C}$ & D \\
\hline 1 & Peteghem and Vanhoucke & 2010 & $\begin{array}{l}\text { MRCPSP and P- } \\
\text { MRCPSP }\end{array}$ & Meta-heuristic BPGA & $\begin{array}{l}\text { PSPLIB } \\
\text { Boctor }\end{array}$ & $\sqrt{ }$ & $\sqrt{ }$ & & \\
\hline 2 & Fundeling and Trautmann & 2010 & PSPWC & $\begin{array}{l}\text { Heuristic } \\
\text { PR }\end{array}$ & Modified PSPLIB & & & $\sqrt{ }$ & \\
\hline 3 & Ranjbar and Kianfar & 2010 & RCPSP-FWP & GA & PSPLIB & & & $\sqrt{ }$ & \\
\hline 4 & Bianco and Caramia & 2013 & RCPSP & Exact method & PSPLIB & $\sqrt{ }$ & & & \\
\hline 5 & Colak et al. & 2013 & MRCPSP-RR & $\begin{array}{l}\text { Heuristic ACE-SP and } \\
\text { meta-heuristic }\end{array}$ & $\begin{array}{l}\text { PSPLIB } \\
\text { Boctor }\end{array}$ & $\sqrt{ }$ & & & \\
\hline 6 & Baumann and Trautmann & 2013 & FRCPSP & MILP & PSPLIB & & & $\sqrt{ }$ & \\
\hline 7 & Naber and Kolisch & 2014 & FRCPSP & MILP & PSPLIB & & & $\sqrt{ }$ & \\
\hline 8 & Peteghem and Vanhoucke & 2014 & $\begin{array}{l}\text { An over view for } \\
\text { MRCPSP }\end{array}$ & $\begin{array}{c}\text { Existing } \\
\text { Meta-heuristic }\end{array}$ & $\begin{array}{l}\text { PSPLIB } \\
\text { Boctor }\end{array}$ & $\sqrt{ }$ & & & \\
\hline 9 & Cheng et al. & 2015 & $\begin{array}{c}\text { (P1-P2-P3) } \\
\text { RCPSP }\end{array}$ & $\begin{array}{c}\text { Exact (B\&B) meth. Heuris- } \\
\text { tics-based PR }\end{array}$ & Modified PSPLIB & $\sqrt{ }$ & $\sqrt{ }$ & & \\
\hline 10 & Ma et al. & 2016 & URCPSP & $\begin{array}{c}\text { Meta-heuristic } \\
\text { GA }\end{array}$ & Modified PSPLIB & $\sqrt{ }$ & & & \\
\hline 11 & Issa and Tu & 2017 & RCPSP & Exact-method B\&B & Own & & $\sqrt{ }$ & & \\
\hline 12 & Elsayed & 2017 & RCPSP & $\mathrm{COA}$ & PSPLIB & $\sqrt{ }$ & & & \\
\hline 13 & Oztemel and Selam & 2017 & MRCPSP & Meta-heuristic $\mathrm{BCO}$ & Own & $\sqrt{ }$ & & & \\
\hline 14 & Naber & 2017 & F-RCPSP & MILP & PSPLIB & & & $\sqrt{ }$ & \\
\hline 15 & Tritschler e.t al. & 2017 & F-RCPSP & HM-GA-VNS & PSPLIB & & & $\sqrt{ }$ & \\
\hline 16 & Nadjafi & 2018 & P-MRCPSP-MC & $\begin{array}{c}\text { Meta-heuristic } \\
\text { SA }\end{array}$ & $\operatorname{ProGen} / \pi \mathrm{x}$ & $\sqrt{ }$ & $\sqrt{ }$ & & \\
\hline 17 & Tao and Dong & 2018 & MRCPSP-APS & $\begin{array}{c}\text { Meta-heuristic } \\
\text { TS }\end{array}$ & PSPLIB & $\sqrt{ }$ & & & \\
\hline 18 & Vanhoucke and Coelho & 2018 & RCPSP-MRCPSP & - & New Datasets & $\sqrt{ }$ & & & \\
\hline
\end{tabular}

\section{Problem description}

The $\operatorname{RCPSP}_{(\mathrm{ABD})}$ can be described as follows: a project consists of a set of activities $i=[1,2, \ldots$, $N]$. The activities are subject to two types of constraints: 1) The precedence constraint, which forces each successor activity to be scheduled after all its predecessor activities are completed; and 2) The limited amount of resources is available during the activities performed. $K=(1, \ldots, k)$, is a set of renewable resource types assigned to activities. Each activity under categories A and $\mathrm{B}, i_{(a, b)}$ , requires constant units of renewable resource, $r\left(i_{(a, b)}, k\right)$, type $k \in K$ during the non-preemptable duration, $d_{i a}$, or during the preemptable duration, $d_{i b}$. Each activity under category $\mathrm{D}, i_{(d)}$, requires work content units, $\omega_{d}$, of renewable resource type $k \in K$ during its preemptable duration, $d_{i_{d}}$. Resource type $k \in K$ has limited availability of $R_{k}$ at any point along the planning horizon.

The objective of the $\operatorname{RCPSP}_{(\mathrm{ABD})}$ is to determine the start and finish times of the project activities, which are classified under A, B, and D categories, subject to scarce resources and precedence relationships to minimize the project makespan. A new algorithm, coded by MATLAB, employs as solving-tool to handling the problem, where many assumptions must be taken into the schedulers' account when he needs to use the model:

1- The duration of activities under category A and B must be pre-determined.

2- The activities under category A cannot be interrupted.

3- The activities under category B can be interrupted.

4- The work content of the activities under category D must be pre-determined and can be interrupted.

5- For each pre-emptive activity, no additional costs required to re-start performing them on later.

6- The resources assigned to each activity are considered as renewable resources.

7- An activity cannot start until all its predecessor activities are finished.

8- The objective is to minimize project makespan. 
In practice, "manufactured-to-order" projects are generally named a one-of-a-kind project (OKP), which aims at producing highly customized projects at nearly mass production efficiency (Tu \& Dean 2011). The project manager in OKP needs to deal with project activities classified under A, $\mathrm{B}$, and $\mathrm{D}$ activity assumptions simultaneously.

\section{Mathematical model}

Many exact methods, heuristics, and meta-heuristics have been proposed for solving RCPSP under $\mathrm{A}, \mathrm{B}$, or $\mathrm{C}$ categories individually. However, the $\mathrm{RCPSP}_{(\mathrm{ABD})}$ has never been studied or handled previously. The mathematical model proposed in this paper employs the following assumptions and notations:

- Project activities can be classified under A, B, and D categories.

- Activities under category A can be executed using constant resources over constant durations and cannot be interrupted through the $\mathrm{X}$-axis or the Time-axes.

- Activities under category B can be implemented using constant resources over constant durations and can be interrupted through the $\mathrm{X}$-axis or the $\mathrm{T}$-axis.

- Activities under category $\mathrm{D}$ can be executed using flexible resources over flexible durations and can be interrupted through the $\mathrm{X}$-axes or the T-axis.

- The model is presented in the Activity-On-Node (AON) format.

- Resources are renewable and have limited capacities.

- Rescheduling activities, from time to time, is allowed due to uncertainties in activity under category D.

\subsection{Inputs}

$i$ number of project activities $\quad i \in P$

$i_{a}$ activities under category $\mathrm{A} \quad i_{a} \in i \quad \forall i \in P$

$i_{b}$ activities under category $\mathrm{B} \quad i_{b} \in i \quad \forall i \in P$

$i_{d}$ activities under category $\mathrm{D} \quad i_{d} \in i \quad \forall i \in P$

$d_{i_{a}}$ durations of activities under category $\mathrm{A}$

$d_{i_{b}}$ durations of activities under category B

$r_{i_{(a, b)}, K}$ renewable resources type $k$ to execute activities under A and B categories $\quad k \in K$

$R_{\text {req }}$ total resource required

$R_{\text {krem }}$ resource remaining

$\omega_{i_{d}} \quad$ work content

$t$ time slots

\subsection{Parameters}

$R_{k} \quad$ amount of available type $k$ resources

$r_{i_{(a, b)}, K}$ resources required to execute activity under $\mathrm{A}$ and $\mathrm{B}$ categories

$\omega_{i_{d}} \quad$ work-content to execute the activity under category D

$d_{i_{(a, b)}}$ duration for activity under A and B categories

$s_{i_{(a, b, d)}} \quad$ The earliest start time for each activity $i$

$f_{i_{(a, b, d)}} \quad$ The earliest finish time for each activity $i$

$T \quad$ time horizon planning

$\mathrm{P}$ portion of work content 


\subsection{Binary variables}

$$
\begin{aligned}
s_{i t} & =\left\{\begin{array}{l}
1 ; \text { if activity } i \text { is started at timeinstant } \mathrm{t} \\
0 ; \text { otherwise }
\end{array}\right. \\
f_{i t} & =\left\{\begin{array}{l}
1 ; \text { if activity } i \text { is finished at timeinstant } t \\
0 ; \text { otherwise }
\end{array}\right. \\
Y_{i t} & =\left\{\begin{array}{c}
1 ; \text { if the categories A \& B are covered by protion of the } \mathrm{R}_{\mathrm{k}} . \\
0 ; \text { if the categories A \& B are covered by the total of the } \mathrm{R}_{\mathrm{k}} .
\end{array}\right.
\end{aligned}
$$

The objective function:

$$
\operatorname{Min} \sum_{i=1}^{n} f_{i+1}
$$

\section{Subject to}

$$
\begin{aligned}
& s_{i}+d_{i} \leq s_{j} \quad \forall(i, j) \in A \\
& \sum_{i_{(a)} \in S_{t}} r_{i_{(a)} k} \leq R_{k} \quad \forall i_{(a)} \in A \\
& \sum_{i_{(b)} \in S_{t}} r_{i_{(b)}} \leq R_{k} \quad \forall i_{(b)} \in A \\
& \sum_{t=s_{i(d)}}^{f_{i_{(d d}-1}} r_{i_{(d)}}=\omega_{i_{(d)}} \quad \forall i_{(d)} \in A \\
& \sum_{t=s_{i_{(d)}}}^{f_{i_{(d d)}-1}} r_{i_{(d)}} \leq R_{k} \quad \forall i_{(d)} \in A \\
& \sum_{i_{(a)} \in s_{t}} r_{i_{(a)} k}+\sum_{i_{(b)} \in s_{t}} r_{i_{(b)} k}+\sum_{t=s_{i(d)}}^{f_{\left.i_{(d d}\right)^{-1}}} r_{i_{(d)} t} \leq R_{k} \\
& s_{i}>0
\end{aligned}
$$

Objective function (1) minimizes the total project's makespan. Constraint sets (2) takes the finishstart precedence relations with a minimal time lag of zero into account. Constraint set (3), (4), and (6) take care of the renewable resource limitation for activities under A, B, and D categories. Constraint (5) defines the work content for each activity under category D. Constraint set (7) ensures that the summation of the resources needed to execute activities under Categories A, B, and D simultaneously must be $\leq R_{k}$. Constraint (8) forces the project to start at time instance zero.

In this section, we illustrate a new solution procedure for the $\operatorname{RCPSP}_{(\mathrm{ABD})}$ with scarce resources, finish to start constraints, and minimum makespan objective at any given time as follows:

1. If the total resource required $\left(R_{\text {req }}\right)$ is less than the available resource $\left(R_{k}\right)$, the available resource needs to be specified in order to complete the project activities.

2. If the activities under A, B, and D are brought together, and if these three need to be executed simultaneously, and if the total resource required $\left(R_{r e q}\right)$ are more than the available resource ( $R_{k}$ ) then the following two sub-loops are executed:

2.1. Assign the available resource $\left(R_{k}\right)$ to the project activities under category $\mathrm{A}$, and calculate the resource remaining $\left(R_{\text {krem }}\right)$, utilizing:

$$
R_{\text {krem }}=R_{k}-r\left(i_{a}, k\right)
$$


2.2.Assign the resource remaining $\left(R_{k r e m}\right)$ to the project activities under category $\mathrm{B}$, calculate the new resource remaining $\left(R_{k \text { rem }}^{\prime}\right)$, and assign the new resource remaining $\left(R_{k \text { rem }}^{\prime}\right)$ to cover a segment of the work content of the activities under category $\mathrm{D}$. This done by:

$$
\begin{aligned}
& R_{\text {krem }}^{\prime}=R_{\text {krem }}-r\left(i_{b}, k\right) \\
& R_{\text {krem }}^{\prime}=P\left(\omega_{i_{d}}\right)
\end{aligned}
$$

3. If project activities under categories A and B need to be executed simultaneously, and if ( $R_{r e q}>R_{k}$ ), then the available resources $\left(R_{k}\right)$ must first be allocated to project activities under category $\mathrm{A}$, and the project activities under category $\mathrm{B}$ must then be delayed to $(\mathrm{t}+1)$.

4. If project activities that need to be executed are under categories (A and D) or (B and D) simultaneously, and if $\left(R_{r e q}>R_{k}\right)$, then the available resources $\left(R_{k}\right)$ must first be allocated to project activities under category A or category B. Then, secondly, a segment of project activities under category D must be covered using the resources remaining $\left(R_{\text {krem }}\right)$. Finally, shift the rest of the work content of the activities to $(t+1)$. These two equations explained this

$$
R_{k}<r_{i_{(a \text { or b }), k}}+\omega_{i_{d}} \quad R_{k}=r_{i_{(a \text { or b }), k}}+P\left(\omega_{i_{d}}\right)
$$

With these results in hand, we can check the resources required to perform the project activities in $(t+1)$ and repeat steps 2 through 4 until all activities in the projects are scheduled.

The concept of Project Management (PM) is the method or technique to complete the project on time. The pre-emption is a way to generate and improve a project schedule that faces the scarce resources assignment on activities over the project duration. Project activities have been assumed to be preemptive in the following papers: (Demeulemeester \& Herrolen 1996; Nudtasomboon \& Randhawa 1997; Valls et al. (1999), Bianco et al., 1999; Brucker \& Knust 2001; Buddhakulsomsiria \& Kim 2006, 2007; Damay 2007; and Peteghem \& Vanhoucke 2010). Besides the difficulty of solving combinatorial optimization problems, the uncertainty, the utilization of scarce resources, and the changes in activities and time durations are the main problems with the scheduling processes. In this research, the problem becomes more much complicated because activities are classified under A, B, and D categories.

Our model-proposed handles scheduling projects, no longer through A, B or C category individually, but through the category A, B, and D simultaneously, where the problems fundamental have been extended to RCPSP problem to $\mathrm{RCPSP}_{(\mathrm{ABD})}$.

Three priority rules are used for activity selection when the conflicts occur; first, the Earliest Start Time (ES); second, the Latest Finish Time (LF); and the Slack Time (SL). These limits, ES, LF, and SL are determined using the traditional forward and backward pass calculations. The backward pass calculation is started from the fixed project makespan, which means that the earliest finish time of the dummy end activity, $\mathrm{EF}_{n}$, is considered as a project makespan and must equal the $\mathrm{LF}_{n} \cdot \mathrm{EF}_{n}$ is computed using the traditional forward pass calculation. The SL can be founded from ( LF-EF).

\section{Numerical example}

In this section, we consider a project consists of 20 activities and three renewable resources. Information of the numerical instance including predecessor activities, durations, and resource utilization are presented in Table 4. 
Table 4

The properties of the project

\begin{tabular}{|c|c|c|c|c|c|c|c|c|c|c|}
\hline Act & Pre. & $\mathrm{D}$ & ES & $\mathrm{EF}$ & LS & LF & $\mathrm{SL}$ & $\mathrm{R} 1$ & $\mathrm{R} 2$ & R3 \\
\hline 1 & - & 0 & 0 & 0 & 0 & 0 & 0 & 0 & 0 & 0 \\
\hline 2 & 1 & 2 & 0 & 6 & 0 & 6 & 0 & 5 & 6 & 2 \\
\hline 3 & 1 & 3 & 0 & 3 & 6 & 9 & 6 & 3 & 5 & 2 \\
\hline 4 & 2,7 & 4 & 6 & 10 & 6 & 10 & 0 & 2 & 4 & 4 \\
\hline 5 & 1 & 6 & 0 & 6 & 7 & 13 & 7 & 5 & 4 & 3 \\
\hline 6 & 2,3 & 7 & 6 & 13 & 9 & 16 & 3 & 3 & 5 & 2 \\
\hline 7 & 4 & 5 & 10 & 15 & 10 & 15 & 0 & 4 & 1 & 4 \\
\hline 8 & 5 & 2 & 6 & 8 & 13 & 15 & 7 & 4 & 1 & 4 \\
\hline 9 & 2,3 & 2 & 6 & 8 & 13 & 15 & 7 & 5 & 5 & 4 \\
\hline 10 & 9,8 & 2 & 8 & 10 & 15 & 17 & 7 & 3 & 2 & 4 \\
\hline 11 & 7 & 6 & 15 & 21 & 15 & 21 & 0 & 1 & 4 & 5 \\
\hline 12 & 4,6 & 1 & 13 & 14 & 16 & 17 & 3 & 3 & 3 & 2 \\
\hline 13 & $6,8,9$ & 2 & 13 & 15 & 17 & 19 & 4 & 3 & 2 & 2 \\
\hline 14 & 10,12 & 4 & 14 & 18 & 17 & 21 & 3 & 2 & 2 & 2 \\
\hline 15 & 7,13 & 2 & 15 & 17 & 19 & 21 & 4 & 1 & 4 & 4 \\
\hline 16 & 13 & 3 & 15 & 18 & 19 & 22 & 4 & 5 & 5 & 4 \\
\hline 17 & $11,14,15$ & 5 & 21 & 26 & 21 & 26 & 0 & 3 & 2 & 3 \\
\hline 18 & 16 & 8 & 18 & 26 & 22 & 30 & 4 & 4 & 5 & 4 \\
\hline 19 & 5,16 & 2 & 18 & 20 & 24 & 26 & 6 & 5 & 3 & 3 \\
\hline 20 & 17,19 & 6 & 26 & 32 & 26 & 32 & 0 & 2 & 4 & 6 \\
\hline 21 & 18 & 2 & 26 & 28 & 30 & 32 & 4 & 1 & 6 & 2 \\
\hline 22 & 18,21 & 0 & 32 & 32 & 32 & 32 & 0 & 0 & 0 & 0 \\
\hline
\end{tabular}

For each activity in Table 4; (Act) is the activity number, (Pre.) represents the predecessor activities, and (D) is the duration of the activity. The forward-backward pass calculation can find the earliest and latest start times (ES and LS) and the earliest and latest finish time (EF and LF) times. The ( SL) is the slack time (i.e., the amount of time that an activity can be delayed without causing another activity to be delayed or impacting the completion date of the project), and (R1, R2, and R3) are the resources required for each activity to be executed. When the resource limitation is not brought in, the project duration, $T_{\min }$, along the critical path can be derived. This is considered as the lower bound of the project makespan. The resource requirements to perform each activity are as indicated in Table 3, and the resource availabilities are $\mathrm{R} 1=7, \mathrm{R} 2=10$, and $\mathrm{R} 3=10$ units.

\subsection{Case study (1)}

The lower bound of project makespan, i.e., the longest period of time on the critical path, takes place when the project manager classifies all the project activities under category A and the resources are unlimited. Each activity starts based on the ES, and when only the precedence relationships constraint among project activities are considered. The lower bound makespan $T_{\text {min }}$ equals 28 days. The non-feasible project schedule occurs due to violations of resource availabilities. As a result, the resource required $\left(R_{\text {req }}\right)$ of $(\mathrm{R} 1, \mathrm{R} 2$, and $\mathrm{R} 3)$ is $=(15,18$, and 15). Table 5 shows the resource utilization and the MORR when project activities are scheduled based on the priority rules ES, LF, and SL.

Table 5

The value of the objective function obtained under ES, LF, and SL priority rules for case 1.

\begin{tabular}{|c|c|c|c|c|c|c|}
\hline \multicolumn{7}{|c|}{ Project activities are classified under category A (ES, LF and SL schedule) } \\
\hline $\begin{array}{l}\text { Resource } \\
\text { type }\end{array}$ & Description & $\begin{array}{c}\text { Maximum re- } \\
\text { source availa- } \\
\text { ble }\end{array}$ & $\begin{array}{c}\text { Resource } \\
\text { available in } \\
\text { project }\end{array}$ & $\begin{array}{c}\text { Resource } \\
\text { used in pro- } \\
\text { ject }\end{array}$ & $\begin{array}{c}\text { Resource } \\
\text { utilization } \\
\% \\
\end{array}$ & MORR \\
\hline 1 & $\mathrm{R} 1$ & 15 & $15 \times 28=420$ & 253 & 60.23 & 2641 \\
\hline 2 & $\mathrm{R} 2$ & 18 & $18 \times 28=432$ & 277 & 64.12 & 3430 \\
\hline 3 & R3 & 15 & $15 \times 28=420$ & 267 & 63.57 & 3529 \\
\hline Average & & & 28 days & & & 3200 \\
\hline
\end{tabular}


Two facts are worth mentioning. One, the amount of resource utilization was low because of the high amount of resource requirements to carry out specific activities during certain periods and to remain idle during the rest periods. Two, project activities are not allowed to be preemptive during the execution time. However, the value of the objective function, when the project activities are classified under category A, precedence relationships and resource constraints are considered, and the resource available $\left(R_{k}\right)$ of $(\mathrm{R} 1, \mathrm{R} 2$, and R3 $)$ is $=(7,10$, and 10), is shown in Tables 6,7 , and 8 respectively:

Table 6

The value of the objective function obtained under ES priority rule for case 1

\begin{tabular}{ccccccc}
\hline \multicolumn{7}{c}{ Project activities are classified under category A (ES schedule) } \\
\hline $\begin{array}{c}\text { Resource } \\
\text { type }\end{array}$ & Description & $\begin{array}{c}\text { Maximum re- } \\
\text { source availa- } \\
\text { ble }\end{array}$ & $\begin{array}{c}\text { Resource } \\
\text { available in } \\
\text { project }\end{array}$ & $\begin{array}{c}\text { Resource } \\
\text { used in pro- } \\
\text { ject }\end{array}$ & $\begin{array}{c}\text { Resource } \\
\text { utilization } \\
\%\end{array}$ & MORR \\
\hline 1 & R1 & 7 & $7 \times 55=385$ & 253 & 65.7 & 6447 \\
2 & R2 & 10 & $10 \times 35=350$ & 277 & 79.14 & 5069 \\
3 & R3 & 10 & $10 \times 35=350$ & 259 & 74 & 4674 \\
\hline Average & \multicolumn{7}{c}{41.6 days } & & 5393.7 \\
\hline
\end{tabular}

Table 7

The value of the objective function obtained under LF priority rule for case 1

\begin{tabular}{ccccccc}
\hline \multicolumn{7}{c}{ Project activities are classified under category A (LF schedule) } \\
\hline $\begin{array}{c}\text { Resource } \\
\text { type }\end{array}$ & Description & $\begin{array}{c}\text { Maximum re- } \\
\text { source availa- } \\
\text { ble }\end{array}$ & $\begin{array}{c}\text { Resource } \\
\text { available in } \\
\text { project }\end{array}$ & $\begin{array}{c}\text { Resource } \\
\text { used in pro- } \\
\text { ject }\end{array}$ & $\begin{array}{c}\text { Resource } \\
\text { utilization } \\
\%\end{array}$ & MORR \\
\hline 1 & R1 & 7 & $7 \times 49=343$ & 253 & 73.76 & 5985 \\
2 & R2 & 10 & $10 \times 35=350$ & 277 & 79.14 & 5182 \\
3 & R3 & 10 & $10 \times 33=330$ & 267 & 80.9 & 4653 \\
\hline Average & & & 39 days & & & 5273.3 \\
\hline
\end{tabular}

\section{Table 8}

The value of the objective function obtained under SL priority rule for case 1

\begin{tabular}{|c|c|c|c|c|c|c|}
\hline \multicolumn{7}{|c|}{ Project activities are classified under category A (SL schedule) } \\
\hline $\begin{array}{l}\text { Resource } \\
\text { type }\end{array}$ & Description & $\begin{array}{l}\text { Maximum re- } \\
\text { source availa- } \\
\text { ble }\end{array}$ & $\begin{array}{c}\text { Resource } \\
\text { available in } \\
\text { project }\end{array}$ & $\begin{array}{c}\text { Resource } \\
\text { used in pro- } \\
\text { ject }\end{array}$ & $\begin{array}{c}\text { Resource } \\
\text { utilization } \\
\%\end{array}$ & MORR \\
\hline 1 & R1 & 7 & $7 \times 46=322$ & 253 & 78.6 & 5930 \\
\hline 2 & $\mathrm{R} 2$ & 10 & $10 \times 37=370$ & 277 & 74.86 & 5440 \\
\hline 3 & R3 & 10 & $10 \times 33=330$ & 259 & 80.9 & 4653 \\
\hline Average & & & 38.6 days & & & 5341 \\
\hline
\end{tabular}

The average project duration is 41.6 days under ES priority rule, 39 days under LF priority rule, and 38.6 days under SL priority rule. The upper bound of project makespan, $\mathrm{T}_{\max }$, is assumed to be 41.6 days.

\subsection{Case study (2)}

Some of the project activities are classified under category A, such as $1,2,4,7,9,11,14,15,17$, 19 and 21; and some other activities are classified under category B, such as 3, 5, 6, 8, 10, 12, 13, 16,18 , and 20. The resources available to execute project activities are 7-units from R1, 10 from $\mathrm{R} 2$, and 10 from R3. Thus, Tables 9, 10, and 11 indicate the value of the objective function obtained under ES, LF, and SL priority rules when project activities are classified under A and B categories: 
Table 9

The value of the objective function obtained under ES priority rule for case 2

\begin{tabular}{|c|c|c|c|c|c|c|}
\hline \multicolumn{7}{|c|}{ Project activities are classified under category A and B (ES schedule) } \\
\hline $\begin{array}{c}\text { Resource } \\
\text { type }\end{array}$ & Description & $\begin{array}{l}\text { Maximum re- } \\
\text { source availa- } \\
\text { ble }\end{array}$ & $\begin{array}{l}\text { Resource } \\
\text { available in } \\
\text { project dur. }\end{array}$ & $\begin{array}{c}\text { Resource } \\
\text { used in pro- } \\
\text { ject }\end{array}$ & $\begin{array}{c}\text { Resource } \\
\text { utilization } \\
\%\end{array}$ & MORR \\
\hline 1 & $\mathrm{R} 1$ & 7 & $7 \times 51=357$ & 253 & 70.8 & 6215 \\
\hline 2 & $\mathrm{R} 2$ & 10 & $10 \times 34=340$ & 277 & 81.4 & 5023 \\
\hline 3 & $\mathrm{R} 3$ & 10 & $10 \times 34=340$ & 267 & 78.5 & 4639 \\
\hline Average & & & 39.6 days & & & 5292.3 \\
\hline
\end{tabular}

Table 10

The value of the objective function obtained under LF priority rule for case 2 Project activities are classified under category A and B (LF schedule)

\begin{tabular}{|c|c|c|c|c|c|c|}
\hline $\begin{array}{c}\text { Resource } \\
\text { type }\end{array}$ & Description & $\begin{array}{l}\text { Maximum re- } \\
\text { source availa- } \\
\text { ble }\end{array}$ & $\begin{array}{c}\text { Resource } \\
\text { available in } \\
\text { project dur. }\end{array}$ & $\begin{array}{c}\text { Resource } \\
\text { used in pro- } \\
\text { ject }\end{array}$ & $\begin{array}{c}\text { Resource } \\
\text { utilization } \\
\% \\
\end{array}$ & MORR \\
\hline 1 & R1 & 7 & $7 \times 49=343$ & 253 & 73.76 & 5937 \\
\hline 2 & $\mathrm{R} 2$ & 10 & $10 \times 34=340$ & 277 & 81.4 & 5023 \\
\hline 3 & $\mathrm{R} 3$ & 10 & $10 \times 34=340$ & 267 & 78.5 & 4653 \\
\hline Average & & & 39 days & & & 15613 \\
\hline
\end{tabular}

\section{Table 11}

The value of the objective function obtained under SL priority rule for case 2

\begin{tabular}{|c|c|c|c|c|c|c|}
\hline \multicolumn{7}{|c|}{ Project activities are classified under category A and B (SL schedule) } \\
\hline $\begin{array}{c}\text { Resource } \\
\text { type }\end{array}$ & Description & $\begin{array}{l}\text { Maximum re- } \\
\text { source availa- } \\
\text { ble }\end{array}$ & $\begin{array}{l}\text { Resource } \\
\text { available in } \\
\text { project dur. }\end{array}$ & $\begin{array}{c}\text { Resource } \\
\text { used in pro- } \\
\text { ject }\end{array}$ & $\begin{array}{c}\text { Resource } \\
\text { utilization } \\
\%\end{array}$ & MORR \\
\hline 1 & $\mathrm{R} 1$ & 7 & $7 \times 52=364$ & 253 & 69.5 & 6391 \\
\hline 2 & $\mathrm{R} 2$ & 10 & $10 \times 34=340$ & 277 & 81.4 & 4963 \\
\hline 3 & $\mathrm{R} 3$ & 10 & $10 \times 33=330$ & 267 & 80.9 & 4653 \\
\hline Average & & & 39.6 days & & & 5335.7 \\
\hline
\end{tabular}

Nonetheless, the average project duration is 39.6 days under ES schedule, 39 days under LF schedule, and 39.6 days under SL schedule.

\subsection{Case study (3)}

Project activities are classified as follows: category A includes activities, such as 1, 2, 4, 7, 9, 11, $14,15,17,19,21$, and 22; category B includes activities, such as 5, 8, 10, 12, 13, 16, and 20; and category D includes activities, such as 3,6, and 18. Tables 12,13, and 14 show the value of the objective function obtained under ES, LF, and SL priority rules when project activities are classified under A, B, and D categories:

Table 12

The value of the objective function obtained under ES priority rule for case 3 .

\begin{tabular}{|c|c|c|c|c|c|c|}
\hline \multicolumn{7}{|c|}{ Project activities are classified under category A, B, and D (ES schedule) } \\
\hline $\begin{array}{l}\text { Resource } \\
\text { type }\end{array}$ & Description & $\begin{array}{l}\text { Maximum re- } \\
\text { source availa- } \\
\text { ble }\end{array}$ & $\begin{array}{c}\text { Resource } \\
\text { available in } \\
\text { project dur. }\end{array}$ & $\begin{array}{c}\text { Resource } \\
\text { used in pro- } \\
\text { ject }\end{array}$ & $\begin{array}{c}\text { Resource } \\
\text { utilization } \\
\%\end{array}$ & MORR \\
\hline 1 & R1 & 7 & $7 \times 41=287$ & 253 & 88.1 & 4930 \\
\hline 2 & $\mathrm{R} 2$ & 10 & $10 \times 32=320$ & 277 & 86.5 & 4524 \\
\hline 3 & R3 & 10 & $10 \times 33=330$ & 267 & 80.9 & 4706 \\
\hline Average & & & 35.3 days & & & 4720 \\
\hline
\end{tabular}


Table 13

The value of the objective function obtained under LF priority rule for case 3

\begin{tabular}{|c|c|c|c|c|c|c|}
\hline \multicolumn{7}{|c|}{ Project activities under are classified under category A, B, and D (LF schedule) } \\
\hline $\begin{array}{l}\text { Resource } \\
\text { type }\end{array}$ & Description & $\begin{array}{l}\text { Maximum re- } \\
\text { source availa- } \\
\text { ble }\end{array}$ & $\begin{array}{l}\text { Resource } \\
\text { available in } \\
\text { project dur. }\end{array}$ & $\begin{array}{l}\text { Resource } \\
\text { used in pro- } \\
\text { ject }\end{array}$ & $\begin{array}{c}\text { Resource } \\
\text { utilization } \\
\% \\
\end{array}$ & MORR \\
\hline 1 & $\mathrm{R} 1$ & 7 & $7 \times 44=287$ & 253 & 82.1 & 5235 \\
\hline 2 & $\mathrm{R} 2$ & 10 & $10 \times 32=320$ & 277 & 86.6 & 4524 \\
\hline 3 & R3 & 10 & $10 \times 33=330$ & 267 & 80.9 & 4694 \\
\hline Average & & & 36.3 days & & & 4817.6 \\
\hline
\end{tabular}

Table 14

The value of the objective function obtained under SL priority rule for case 3

\begin{tabular}{|c|c|c|c|c|c|c|}
\hline \multicolumn{7}{|c|}{ Project activities are classified under category A, B, and D (SL schedule) } \\
\hline $\begin{array}{l}\text { Resource } \\
\text { type }\end{array}$ & Description & $\begin{array}{l}\text { Maximum re- } \\
\text { source availa- } \\
\text { ble }\end{array}$ & $\begin{array}{l}\text { Resource } \\
\text { available in } \\
\text { project dur. }\end{array}$ & $\begin{array}{c}\text { Resource } \\
\text { used in pro- } \\
\text { ject }\end{array}$ & $\begin{array}{c}\text { Resource } \\
\text { utilization } \\
\% \\
\end{array}$ & MORR \\
\hline 1 & R1 & 7 & $7 \times 41=287$ & 253 & 88.1 & 4930 \\
\hline 2 & $\mathrm{R} 2$ & 10 & $10 \times 32=320$ & 277 & 86.6 & 4524 \\
\hline 3 & R3 & 10 & $10 \times 33=330$ & 267 & 80.9 & 4706 \\
\hline Average & & & 35.3 days & & & 4720 \\
\hline
\end{tabular}

The average project makespan is reduced to 35.3 days under the ES schedule, 36.3 days under the LF schedule, and 35.3 under the SL schedule. Resources required $\left(R_{\text {req }}\right)$ of $(\mathrm{R} 1, \mathrm{R} 2$, and R3 $)=(7$, 10 , and 10$)$, and resource availability $\left(R_{k}\right)$ of $(\mathrm{R} 1, \mathrm{R} 2$, and $\mathrm{R} 3)=(7,10$, and 10$)$. The compression between $\left(R_{\text {req }}\right)$ and $\left(R_{k}\right)$ indicates that no resource conflict occurs. Table 15, therefore, shows the best way to schedule the activities when project schedulers classify the activities under (A, B, and D) categories. The less duration and MORR (in Bold) are obtained under ES and SL priority rules.

\section{Table 15}

The value of the average duration and MORR for cases 1,2 , and 3 .

\begin{tabular}{ccc|cc|cc}
\hline \multicolumn{2}{c|}{$\begin{array}{c}\text { Activities classified under category } \\
\text { A }\end{array}$} & $\begin{array}{c}\text { Activities classified under category } \\
\text { A and B }\end{array}$ & $\begin{array}{c}\text { Activities classified under category } \\
\text { A, B, and D }\end{array}$ \\
\hline PR & (Duration & MORR.) & (Duration & MORR.) & (Duration & MORR.) \\
\hline ES & 38.6 & 5341 & 39.6 & 5292.3 & $\mathbf{3 5 . 3}$ & $\mathbf{4 7 2 0}$ \\
LF & 39 & 5273.3 & 39 & 5204.3 & 36.3 & 4817.6 \\
SL & 41.6 & 5393.7 & 39.6 & 5335.7 & $\mathbf{3 5 . 3}$ & $\mathbf{4 7 2 0}$ \\
\hline
\end{tabular}

\section{Computational results}

Based on the literature, test instances which classify project activities under A, B, and D categories are unavailable. Therefore, this section presents the results obtained using the proposed model with the PSPLIB modified instances. J30 and J60 activities are generated by Kolisch and Sprecher (1996). The experiments share some common characteristics, including, for example, the utilization of renewable resources.

Three parameters have been changed as follows:

1) The network complexity (NC) defines the average number of predecessors per activity.

2) The resource factor (RF) determines the average percentages of different resource types.

3) The resource strength (RS) defines the degree of the strength of resources.

Because of classified project activities to A, B, and D categories, the results obtained from the experiment provide insight into the makespan improvement. This improvement is measured and calculated as follows:

$\%$ makespan improvment $=\frac{[\text { makespan }(\text { under category } \mathrm{A})-\text { makespan }(\text { under category } \mathrm{AB} \text { or } \mathrm{AB} \mathrm{D})]}{\text { makespan }(\text { under category } \mathrm{A})}$ 
As can be seen in Table A.1, the greater chance to larger the makespan improvement can be found when project activities are classified under A, B, and D categories.

Equally important, the three results from Appendix A are diagrammed in Figure 5 in graphics format: the best makespan, the best resource utilization, and the best MORR can be found when project activities are classified under A, B, and C categories.
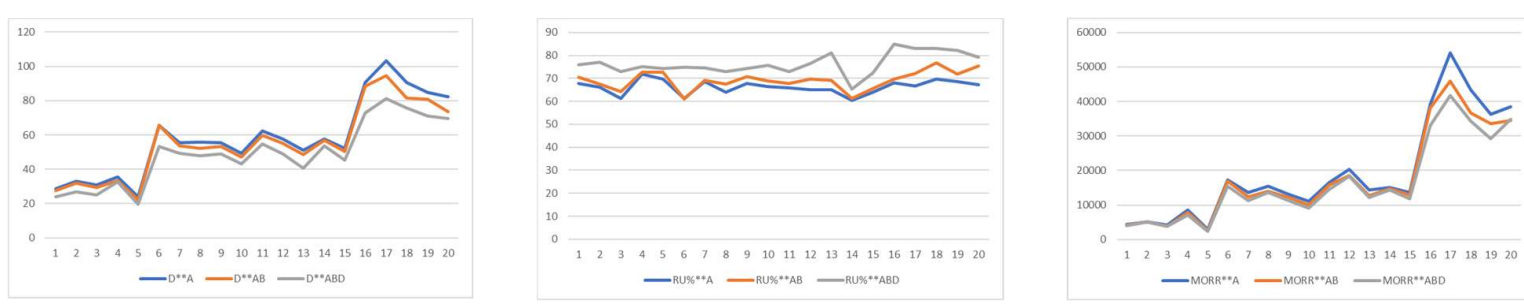

Fig. 5. Duration, resource utilization, and MORR. criterion in graphic format.

The impact of activity assumptions has been measured using the following criteria: the average of resource utilization, the average of MORR criterion, and the average of the project makespan improvement, as depicted in Table A. 1. Classify project activities, only, under category A (i.e., when the problem is considered as $\mathrm{RCPSP}_{(\mathrm{A})}$ will be used as a reference to measure any improvement can occur compared with the (RCPSP $_{(\mathrm{AB})}$ or P-RCPSP) and with the ( $\mathrm{RCPSP}_{(\mathrm{ABD})}$ or F-P-RCPSP) activity assumptions.

The results can be summarized as follows: classifying project activities under "AB" can occur little improvement $(4.9 \%)$ in the average of the percentage of the project-makespan-improvement whereas, classifying project activities under "ABD" increases the average of the percentage of the project-makespan-improvement (15.8\%), as shown in Table A. 1 (in Bold).

\section{Conclusion}

In this paper, we present new procedures for scheduling projects under three generals of the project activities assumptions simultaneously, i.e., A, B, and D. For example, the activities under category A can be executed using constant resources over constant durations, and the pre-emptions are not allowed. The activities under category $\mathrm{B}$ can be executed using constant resources over constantan durations, the pre-emptions are allowed. The activities under category $\mathrm{D}$ can be executed using flexible resources over flexible durations, and the pre-emptions are allowed. With A, B, and D categories project schedulers can provide more flexibility in planning and scheduling projects constrained by limited multi-type of resources. In practice, many projects in construction and manufacturing-engineering include these three general categories. That is, project schedulers can interrupt (plan) activities under categories B and D. Our approach gives more flexibility to optimizing the project schedule and also offers a distinctive direction for project planning and scheduling. As seen in the three case studies, the project manager can split project activities, resulting in decreasing project duration and increasing average resource utilization.

\section{References}

Afshar-Nadjafi, B. (2018). A solution procedure for preemptive multi-mode project scheduling problem with mode changeability to resumption. Applied Computing and Informatics, 14(2), 192-201.

Baumann, P., \& Trautmann, N. (2013). Optimal scheduling of work-content-constrained projects. In 2013 IEEE International Conference on Industrial Engineering and Engineering Management (pp. 395-399). IEEE.

Bianco, L., Caramia, M., \& Dell'Olmo, P. (1999). Solving a preemptive project scheduling problem with coloring techniques. In Project Scheduling (pp. 135-145). Springer, Boston, MA. 
Bianco, L., \& Caramia, M. (2013). A new formulation for the project scheduling problem under limited resources. Flexible Services and Manufacturing Journal, 25(1-2), 6-24.

Brucker, P., \& Knust, S. (2000, August). Resource-constrained project scheduling and timetabling. In International Conference on the Practice and Theory of Automated Timetabling (pp. 277293). Springer, Berlin, Heidelberg.

Buddhakulsomsiri, J., \& Kim, D. S. (2006). Properties of multi-mode resource-constrained project scheduling problems with resource vacations and activity splitting. European Journal of Operational Research, 175(1), 279-295.

Buddhakulsomsiri, J., \& Kim, D. S. (2007). Priority rule-based heuristic for multi-mode resourceconstrained project scheduling problems with resource vacations and activity splitting. European Journal of Operational Research, 178(2), 374-390.

Cheng, J., Fowler, J., Kempf, K., \& Mason, S. (2015). Multi-mode resource-constrained project scheduling problems with non-preemptive activity splitting. Computers \& Operations Research, 53, 275-287.

Colak, S., Agarwal, A., \& Erenguc, S. (2013). Multi-mode resource-constrained project-scheduling problem with renewable resources: new solution approaches. Journal of Business \& Economics Research (Online), 11(11), 455.

Damay, J., Quilliot, A., \& Sanlaville, E. (2007). Linear programming-based algorithms for preemptive and non-preemptive RCPSP. European Journal of Operational Research, 182(3), 10121022.

Demeulemeester, E. L., \& Herroelen, W. S. (1996). An efficient optimal solution procedure for the preemptive resource-constrained project scheduling problem. European Journal of Operational Research, 90(2), 334-348.

Elsayed, S., Sarker, R., Ray, T., \& Coello, C. C. (2017). Consolidated optimization algorithm for resource-constrained project scheduling problems. Information Sciences, 418, 346-362.

Fang, C., \& Wang, L. (2012). An effective shuffled frog-leaping algorithm for resource-constrained project scheduling problem. Computers \& Operations Research, 39(5), 890-901.

Fündeling, C. U., \& Trautmann, N. (2010). A priority-rule method for project scheduling with workcontent constraints. European Journal of Operational Research, 203(3), 568-574.

Hartmann, S., \& Briskorn, D. (2010). A survey of variants and extensions of the resource-constrained project scheduling problem. European Journal of operational research, 207(1), 1-14.

Hartmann, S., \& Kolisch, R. (2000). Experimental evaluation of state-of-the-art heuristics for the resource-constrained project scheduling problem. European Journal of Operational Research, 127(2), 394-407.

Issa, S., \& Tu, Y. (2017). Integrated multi-resource planning and scheduling in an engineering project. Journal of Project Management, 2(1), 11-26.

Kellenbrink, C., \& Helber, S. (2015). Scheduling resource-constrained projects with a flexible project structure. European Journal of Operational Research, 246(2), 379-391.

Kolisch, R., \& Hartmann, S. (1999). Heuristic algorithms for the resource-constrained project scheduling problem: Classification and computational analysis. In Project scheduling (pp. 147178). Springer, Boston, MA.

Kolisch, R., \& Hartmann, S. (2006). Experimental investigation of heuristics for resource-constrained project scheduling: An update. European journal of operational research, 174(1), 2337.

Sprecher, A., \& Kolisch, R. (1996). PSPLIB - a project scheduling problem library. Eur. J. Oper. Res, 96, 205-216.

Ma, W., Che, Y., Huang, H., \& Ke, H. (2016). Resource-constrained project scheduling problem with uncertain durations and renewable resources. International journal of machine learning and cybernetics, 7(4), 613-621.

Naber, A. (2017). Resource-constrained project scheduling with flexible resource profiles in continuous time. Computers \& Operations Research, 84, 33-45.

Naber, A., \& Kolisch, R. (2014). MIP models for resource-constrained project scheduling with flexible resource profiles. European Journal of Operational Research, 239(2), 335-348. 
Nudtasomboon, N., \& Randhawa, S. U. (1997). Resource-constrained project scheduling with renewable and non-renewable resources and time-resource tradeoffs. Computers \& Industrial Engineering, 32(1), 227-242.

Oztemel, E., \& Selam, A. A. (2017). Bees Algorithm for multi-mode, resource-constrained project scheduling in molding industry. Computers \& Industrial Engineering, 112, 187-196.

Ranjbar, M., \& Kianfar, F. (2010). Resource-constrained project scheduling problem with flexible work profiles: a genetic algorithm approach. Scientia Iranica. Transaction E, Industrial Engineering, 17(1), 25.

Tao, S., \& Dong, Z. S. (2018). Multi-mode resource-constrained project scheduling problem with alternative project structures. Computers \& Industrial Engineering, 125, 333-347.

Tritschler, M., Naber, A., \& Kolisch, R. (2017). A hybrid metaheuristic for resource-constrained project scheduling with flexible resource profiles. European Journal of Operational Research, 262(1), 262-273.

Tu, Y., \& Dean, P. (2011). One-of-a-kind Production. Springer Science \& Business Media.

Valls, V., Laguna, M., Lino, P., Pérez, A., \& Quintanilla, S. (1999). Project scheduling with stochastic activity interruptions. Project scheduling (pp. 333-353). Springer, Boston, MA.

Vanhoucke, M., \& Coelho, J. (2018). A tool to test and validate algorithms for the resource-constrained project scheduling problem. Computers \& Industrial Engineering, 118, 251-265.

Van Peteghem, V., \& Vanhoucke, M. (2010). A genetic algorithm for the preemptive and nonpreemptive multi-mode resource-constrained project scheduling problem. European Journal of Operational Research, 201(2), 409-418.

Van Peteghem, V., \& Vanhoucke, M. (2014). An experimental investigation of metaheuristics for the multi-mode resource-constrained project scheduling problem on new dataset instances. European Journal of Operational Research, 235(1), 62-72.

Zhang, H., Li, H., \& Tam, C. M. (2006). Particle swarm optimization for resource-constrained project scheduling. International Journal of Project Management, 24(1), 83-92.

\section{Appendix A}

As used in this paper, the problem instants are modifications of PSPLIB created by Kolisch and Sprecher (1996). In order to investigate the impact of (A, B, and D) activity assumptions, activities for each project are classified under three assumptions: first assumption is: all the activities are classified under category A. Second assumption is: some activities are classified under category A and the rest under category B. Third assumption is: some activities are classified under category A, some under category $\mathrm{B}$, and the rest under category $\mathrm{D}$. The makespan (D), the resource utilization (RU), the minimum moment of resource required (MORR) criterion, the \% of makespan improvement are four indicators that have been measured for each problem with ES, LF, and SL priority rules. Each project has nine feasible schedules. The first three schedules are generated when the activities are classified under category A with ES, LF, and SL priority rules. The following three schedules are generated when activities are classified under A and B categories with ES, LF, and SL. The last three schedules are generated when the activities are classified under (A, B and D) categories with ES, LF, and SL. The average of each indicator, (i.e., D, RU, MORR, and makespan improvement) has been measured for three feasible schedules under each category, as depicted in Table A.1. The procedure to get the results was programmed in MATLAB (R2018a), executed on a personal computer with an Intel(R) Core (TM) 2 Duo CPU T6500@2.10 GHz, 4GB RAM, and Windows 7. 
Table A.1 The problem instances used in the paper

\begin{tabular}{|c|c|c|c|c|c|c|c|c|c|c|c|c|c|c|c|c|}
\hline Project & Cat. & NC & RF & RS & R1 & R2 & R3 & R4 & PR. & D & RU\% & MORR & $\begin{array}{c}\text { Aver. } \\
\text { D }\end{array}$ & $\begin{array}{l}\text { Aver. } \\
\text { RU\% }\end{array}$ & $\begin{array}{c}\text { Aver. } \\
\text { MORR }\end{array}$ & $\begin{array}{c}\% \text { I } \\
\text { mpr. }\end{array}$ \\
\hline \multirow{8}{*}{$\begin{array}{c}1 \\
\mathrm{~J} 30\end{array}$} & $\mathrm{~A}$ & 1.5 & 0.25 & 0.2 & \multirow{8}{*}{12} & \multirow{8}{*}{13} & \multirow{8}{*}{4} & \multirow{8}{*}{12} & $\begin{array}{l}\text { ES } \\
\text { LF }\end{array}$ & $\begin{array}{l}30.25 \\
27.75\end{array}$ & $\begin{array}{l}66.42 \\
68.86\end{array}$ & $\begin{array}{c}4537 \\
4252.3\end{array}$ & 28.75 & 67.80 & 4446 & 0.0 \\
\hline & & & & & & & & & SL & 28.25 & 68.10 & 4550.8 & & & & \\
\hline & $\mathrm{AB}$ & 1.5 & 0.25 & 0.2 & & & & & ES & 27.5 & 70.38 & 4346.3 & & & & \\
\hline & & & & & & & & & LF & 27.5 & 70.45 & 4254.8 & 27.5 & 70.433 & 4285.3 & 4.3 \\
\hline & & & & & & & & & $\mathrm{SL}$ & 27.5 & 70.45 & 4254.8 & & & & \\
\hline & $\mathrm{ABD}$ & 1.5 & 0.25 & 0.2 & & & & & ES & 24.25 & 75.25 & 4027 & & & & \\
\hline & & & & & & & & & $\mathrm{LF}$ & 23.75 & 76.37 & 4012.3 & 23.92 & 76.00 & 4017 & 16.8 \\
\hline & & & & & & & & & $\mathrm{SL}$ & 23.75 & 76.37 & 4012.3 & & & & \\
\hline & A & 1.5 & 0.25 & 0.2 & & & & & $\begin{array}{l}\text { ES } \\
\text { LF }\end{array}$ & $\begin{array}{l}32.75 \\
33.75\end{array}$ & $\begin{array}{c}64.28 \\
63.9\end{array}$ & $\begin{array}{l}5133.3 \\
5296.3\end{array}$ & 32.83 & 66.20 & 5207 & 0.0 \\
\hline 2 & & & & & & & & & SL & 32 & 70.42 & 5193.3 & & & & \\
\hline $\mathrm{J} 30$ & $\mathrm{AB}$ & 1.5 & 0.25 & 0.2 & 14 & 10 & 11 & 14 & ES & 31.75 & 66.43 & 5044.3 & & & & \\
\hline & & & & & & & & & $\mathrm{LF}$ & 31.75 & 67.83 & 5059.3 & 31.75 & 67.37 & 5063 & 3.3 \\
\hline & & & & & & & & & $\mathrm{SL}$ & 31.75 & 67.83 & 5087.3 & & & & \\
\hline & $\mathrm{ABD}$ & 1.5 & 0.25 & 0.2 & & & & & ES & 26.75 & 77.03 & 5157.3 & & & & \\
\hline & & & & & & & & & $\mathrm{LF}$ & 26.75 & 77.03 & 5157.3 & 26.75 & 77.03 & 5164 & 18.5 \\
\hline & & & & & & & & & SL & 26.75 & 77.03 & 5178.5 & & & & \\
\hline & A & 1.5 & 0.25 & 0.2 & & & & & ES & 29.75 & 63.02 & 3944.8 & & & & \\
\hline & & & & & & & & & $\mathrm{LF}$ & 31.25 & 60.05 & 4284.8 & 30.67 & 61.19 & 4184 & 0.0 \\
\hline 3 & & & & & & & & & SL & 31 & 60.48 & 4322.5 & & & & \\
\hline $\mathrm{J} 30$ & $\mathrm{AB}$ & 1.5 & 0.25 & 0.2 & 10 & 8 & 13 & 12 & ES & 29.75 & 63.02 & 3944.8 & & & & \\
\hline & & & & & & & & & $\mathrm{LF}$ & 29 & 65.03 & 3879.3 & 29.25 & 64.36 & 3921 & 4.6 \\
\hline & & & & & & & & & SL & 29 & 65.03 & 3939.3 & & & & \\
\hline & ABD & 1.5 & 0.25 & 0.2 & & & & & ES & 25 & 72.84 & 3845 & & & & \\
\hline & & & & & & & & & LF & 25 & 72.84 & 3839 & 25.00 & 72.85 & 3841 & 18.5 \\
\hline & & & & & & & & & SL & 25 & 72.84 & 3839 & & & & \\
\hline & A & 1.5 & 0.25 & 0.2 & & & & & ES & 35.5 & 72.01 & 8112 & & & & \\
\hline & & & & & & & & & LF & 35.25 & 72.48 & 8716.5 & 35.50 & 71.73 & 8515 & 0.0 \\
\hline 4 & & & & & & & & & SL & 35.75 & 70.68 & 8719 & & & & \\
\hline $\mathrm{J} 30$ & $\mathrm{AB}$ & 1.5 & 0.25 & 0.2 & 7 & 11 & 11 & 15 & ES & 33 & 73.42 & 7691.5 & & & & \\
\hline & & & & & & & & & $\begin{array}{l}\text { LF } \\
\text { SL }\end{array}$ & $\begin{array}{c}33 \\
34.5\end{array}$ & $\begin{array}{l}73.42 \\
71.51\end{array}$ & $\begin{array}{c}7717 \\
7876.8\end{array}$ & 33.50 & 72.79 & 7761 & 5.6 \\
\hline & $\mathrm{ABD}$ & 1.5 & 0.25 & 0.2 & & & & & ES & 32.5 & 75.04 & 7100.8 & & & & \\
\hline & & & & & & & & & LF & 32.5 & 75.04 & 7113.5 & 32.50 & 75.04 & 7109 & 8.5 \\
\hline & & & & & & & & & $\mathrm{SL}$ & 32.5 & 75.04 & 7113.5 & & & & \\
\hline & A & 1.5 & 0.25 & 0.2 & & & & & ES & 21.5 & 74.35 & 2531 & & & & \\
\hline 5 & & & & & & & & & $\begin{array}{l}\text { LF } \\
\text { SL }\end{array}$ & $\begin{array}{l}25 \\
25\end{array}$ & $\begin{array}{l}67.33 \\
67.33\end{array}$ & $\begin{array}{c}3242 \\
3294.8\end{array}$ & 23.83 & 69.67 & 3022 & 0.0 \\
\hline $\mathrm{J} 30$ & $\mathrm{AB}$ & 1.5 & 0.25 & 0.2 & 11 & 11 & 9 & 11 & ES & 21.5 & 74.35 & 2521.8 & & & & \\
\hline & & & & & & & & & LF & 22.5 & 71.95 & 2624.3 & 22.25 & 72.59 & 2601 & 6.6 \\
\hline & & & & & & & & & SL & 22.75 & 71.47 & 2657.5 & & & & \\
\hline & $\mathrm{ABD}$ & 1.5 & 0.25 & 0.2 & & & & & $\begin{array}{l}\text { ES } \\
\text { LF }\end{array}$ & $\begin{array}{c}19.75 \\
19.5\end{array}$ & $\begin{array}{l}74.32 \\
75.01\end{array}$ & $\begin{array}{l}2349.3 \\
2346.5\end{array}$ & 19.75 & 74.34 & 2350 & 17.1 \\
\hline & & & & & & & & & SL & 20 & 73.67 & 2356.3 & & & & \\
\hline & A & 1.8 & 0.5 & 0.5 & & & & & ES & 66 & 60.52 & 17086 & & & & \\
\hline & & & & & & & & & $\mathrm{LF}$ & 64.5 & 61.77 & 17149 & 65.75 & 61.27 & 17322 & 0.0 \\
\hline 6 & & & & & & & & & SL & 66.75 & 61.50 & 17732 & & & & \\
\hline $\mathrm{J} 30$ & $\mathrm{AB}$ & 1.8 & 0.5 & 0.5 & 11 & 12 & 12 & 8 & ES & 65.5 & 60.90 & 16871 & & & & \\
\hline & & & & & & & & & $\begin{array}{l}\text { LF } \\
\text { SL }\end{array}$ & $\begin{array}{l}64.75 \\
66.25\end{array}$ & $\begin{array}{l}61.72 \\
60.46\end{array}$ & $\begin{array}{l}16691 \\
16956\end{array}$ & 65.50 & 61.03 & 16839 & 0.4 \\
\hline & $\mathrm{ABD}$ & 1.8 & 0.5 & 0.5 & & & & & ES & 53.25 & 75.09 & 15533 & & & & \\
\hline & & & & & & & & & LF & 53 & 75.47 & 15476 & 53.33 & 74.97 & 15528 & 18.9 \\
\hline & & & & & & & & & SL & 53.75 & 74.32 & 15576 & & & & \\
\hline & A & 1.8 & 0.5 & 0.5 & & & & & ES & & 65.55 & 13620 & & & & \\
\hline & & & & & & & & & LF & 56.25 & 68.52 & 13807 & 55.50 & 68.55 & 13716 & 0.0 \\
\hline 7 & & & & & & & & & SL & 53.75 & 71.57 & 13721 & & & & \\
\hline $\mathrm{J} 30$ & $\mathrm{AB}$ & 1.8 & 0.5 & 0.5 & 13 & 12 & 12 & 12 & ES & 54.75 & 69.92 & 12550 & & & & \\
\hline & & & & & & & & & LF & 53 & 69.06 & 12211 & 53.75 & 69.16 & 12325 & 3.2 \\
\hline & & & & & & & & & SL & 53.5 & 68.49 & 12216 & & & & \\
\hline & ABD & 1.8 & 0.5 & 0.5 & & & & & ES & 51 & 71.96 & 11661 & & & & \\
\hline & & & & & & & & & $\mathrm{LF}$ & 48.25 & 75.69 & 11048 & 49.17 & 74.45 & 11252 & 11.4 \\
\hline & & & & & & & & & $\mathrm{SL}$ & 48.25 & 75.69 & 11048 & & & & \\
\hline & A & 1.8 & 0.5 & 0.5 & & & & & ES & 57.5 & 63.72 & 15841 & & & & \\
\hline 8 & & & & & & & & & $\begin{array}{l}\text { LF } \\
\text { SL }\end{array}$ & $\begin{array}{c}54.25 \\
55.5\end{array}$ & $\begin{array}{l}64.47 \\
63.35\end{array}$ & $\begin{array}{l}14908 \\
15488\end{array}$ & 55.75 & 63.85 & 15412 & 0.0 \\
\hline $\mathrm{J} 30$ & $\mathrm{AB}$ & 1.8 & 0.5 & 0.5 & 15 & 12 & 12 & 11 & ES & 52 & 67.71 & 13960 & & & & \\
\hline & & & & & & & & & $\begin{array}{l}\text { LF } \\
\text { SL }\end{array}$ & $\begin{array}{c}52 \\
52.25\end{array}$ & $\begin{array}{l}67.71 \\
67.45\end{array}$ & $\begin{array}{l}13887 \\
13936\end{array}$ & 52.08 & 67.63 & 13927 & 6.6 \\
\hline & $\mathrm{ABD}$ & 1.8 & 0.5 & 0.5 & & & & & ES & 48.25 & 72.47 & 13735 & & & & \\
\hline & & & & & & & & & LF & 47.75 & 73.15 & 13603 & 47.92 & 72.93 & 13647 & 14.1 \\
\hline & & & & & & & & & $\mathrm{SL}$ & 47.75 & 73.15 & 13603 & & & & \\
\hline & $\mathrm{A}$ & 1.8 & 0.5 & 0.5 & & & & & ES & 55.25 & 68.65 & 12553 & & & & \\
\hline & & & & & & & & & LF & 54 & 67.95 & 12925 & 55.33 & 67.66 & 13191 & 0.0 \\
\hline 9 & & & & & & & & & SL & 56.75 & 66.36 & 14097 & & & & \\
\hline $\mathrm{J} 30$ & $\mathrm{AB}$ & 1.8 & 0.5 & 0.5 & 9 & 16 & 12 & 12 & ES & 54.25 & 70.14 & 12183 & & & & \\
\hline & & & & & & & & & LF & 51.5 & 71.96 & 12232 & 53.33 & 70.89 & 12204 & 3.6 \\
\hline & ABD & 1.8 & 0.5 & 0.5 & & & & & $\begin{array}{l}\text { SL } \\
\text { ES }\end{array}$ & $\begin{array}{l}54.25 \\
49.25\end{array}$ & $\begin{array}{l}70.56 \\
73.94\end{array}$ & $\begin{array}{l}12198 \\
11271\end{array}$ & & & & \\
\hline & & & & & & & & & LF & 49.25 & 73.97 & 11270 & 48.92 & 74.42 & 11238 & 11.6 \\
\hline
\end{tabular}




\begin{tabular}{|c|c|c|c|c|c|c|c|c|c|c|c|c|c|c|c|c|}
\hline & \multicolumn{15}{|c|}{ S. Ben Issa and Y. Tu / Journal of Project Management 5 (2020) } & \multirow[t]{2}{*}{57} \\
\hline & & & & & & & & & SL & 48.25 & 75.33 & 11173 & & & & \\
\hline \multirow{4}{*}{$\begin{array}{c}10 \\
\mathrm{~J} 30\end{array}$} & A & 1.8 & 0.5 & 0.5 & \multirow{4}{*}{14} & \multirow{4}{*}{15} & \multirow{4}{*}{11} & \multirow{4}{*}{11} & $\begin{array}{l}\text { ES } \\
\text { LF } \\
\text { SL }\end{array}$ & $\begin{array}{c}50.5 \\
48 \\
49 \\
\end{array}$ & $\begin{array}{l}64.50 \\
67.94 \\
67.02 \\
\end{array}$ & $\begin{array}{l}10709 \\
11041 \\
11539 \\
\end{array}$ & 49.17 & 66.49 & 11096 & 0.0 \\
\hline & $\mathrm{AB}$ & 1.8 & 0.5 & 0.5 & & & & & $\begin{array}{l}\text { ES } \\
\text { LF }\end{array}$ & $\begin{array}{l}48.75 \\
45.75\end{array}$ & $\begin{array}{l}66.70 \\
70.96\end{array}$ & $\begin{array}{c}10075 \\
9951\end{array}$ & 47.17 & 68.96 & 10072 & 4.1 \\
\hline & ABD & 1.8 & 0.5 & 0.5 & & & & & $\frac{\mathrm{SL}}{\mathrm{ES}}$ & $\frac{47}{43.25}$ & $\frac{69.19}{75.06}$ & $\frac{10192}{9277.3}$ & & & & \\
\hline & & & & & & & & & $\begin{array}{l}\mathrm{LF} \\
\mathrm{SL}\end{array}$ & $\begin{array}{c}42.25 \\
43.5 \\
\end{array}$ & $\begin{array}{l}76.78 \\
74.70 \\
\end{array}$ & $\begin{array}{r}9104.8 \\
9199.3 \\
\end{array}$ & 43.00 & 75.52 & 9193 & 12.5 \\
\hline \multirow{3}{*}{$\begin{array}{c}11 \\
\text { J60 }\end{array}$} & A & 1.5 & 0.25 & 0.2 & \multirow{3}{*}{13} & \multirow{3}{*}{11} & \multirow{3}{*}{12} & \multirow{3}{*}{13} & $\begin{array}{l}\text { ES } \\
\text { LF } \\
\text { SL }\end{array}$ & $\begin{array}{c}58.75 \\
64.75 \\
63.5 \\
\end{array}$ & $\begin{array}{l}67.89 \\
64.07 \\
65.74 \\
\end{array}$ & $\begin{array}{l}16174 \\
16955 \\
16781 \\
\end{array}$ & 62.33 & 65.91 & 16636 & 0.0 \\
\hline & $\mathrm{AB}$ & 1.5 & 0.25 & 0.2 & & & & & $\begin{array}{l}\text { ES } \\
\text { LF } \\
\text { SL } \\
\end{array}$ & $\begin{array}{l}58.25 \\
58.75 \\
62.25 \\
\end{array}$ & $\begin{array}{l}68.40 \\
69.36 \\
65.43 \\
\end{array}$ & $\begin{array}{l}15540 \\
15632 \\
16325 \\
\end{array}$ & 59.75 & 67.73 & 15832 & 4.1 \\
\hline & $\mathrm{ABD}$ & 1.5 & 0.25 & 0.2 & & & & & $\begin{array}{l}\text { ES } \\
\text { LF } \\
\text { SL }\end{array}$ & $\begin{array}{c}53.5 \\
55 \\
55.75\end{array}$ & $\begin{array}{l}74.44 \\
72.66 \\
71.61\end{array}$ & $\begin{array}{l}14294 \\
14378 \\
14848\end{array}$ & 54.75 & 72.91 & 14506 & 12.2 \\
\hline \multirow{3}{*}{$\begin{array}{c}12 \\
\mathrm{~J} 60\end{array}$} & $\mathrm{~A}$ & 1.5 & 0.25 & 0.2 & \multirow{3}{*}{13} & \multirow{3}{*}{15} & \multirow{3}{*}{14} & \multirow{3}{*}{14} & $\begin{array}{l}\text { ES } \\
\text { LF } \\
\text { SL }\end{array}$ & $\begin{array}{l}56.75 \\
54.75 \\
61.75 \\
\end{array}$ & $\begin{array}{l}66.79 \\
67.77 \\
60.96 \\
\end{array}$ & $\begin{array}{l}18534 \\
20126 \\
22430 \\
\end{array}$ & 57.75 & 65.17 & 20363 & 0.0 \\
\hline & $\mathrm{AB}$ & 1.5 & 0.25 & 0.2 & & & & & $\begin{array}{l}\text { ES } \\
\text { LF } \\
\text { SL } \\
\end{array}$ & $\begin{array}{c}56 \\
54.25 \\
55.5 \\
\end{array}$ & $\begin{array}{l}68.13 \\
72.31 \\
68.18 \\
\end{array}$ & $\begin{array}{l}18725 \\
18374 \\
18649 \\
\end{array}$ & 55.25 & 69.55 & 18582 & 4.3 \\
\hline & $\mathrm{ABD}$ & 1.5 & 0.25 & 0.2 & & & & & $\begin{array}{l}\text { ES } \\
\text { LF } \\
\text { SL }\end{array}$ & $\begin{array}{c}48.75 \\
49.25 \\
49\end{array}$ & $\begin{array}{l}76.39 \\
76.29 \\
76.66\end{array}$ & $\begin{array}{l}18103 \\
18386 \\
18385\end{array}$ & 49.00 & 76.45 & 18291 & 15.2 \\
\hline \multirow{3}{*}{$\begin{array}{c}13 \\
\mathrm{~J} 60\end{array}$} & $\mathrm{~A}$ & 1.5 & 0.25 & 0.2 & \multirow{3}{*}{16} & \multirow{3}{*}{19} & \multirow{3}{*}{14} & \multirow{3}{*}{12} & $\begin{array}{l}\text { ES } \\
\text { LF } \\
\text { SL }\end{array}$ & $\begin{array}{c}49.5 \\
50.5 \\
53.25\end{array}$ & $\begin{array}{l}67.07 \\
65.13 \\
62.88\end{array}$ & $\begin{array}{l}12931 \\
14630 \\
15384\end{array}$ & 51.08 & 65.03 & 14315 & 0.0 \\
\hline & $\overline{\mathrm{AB}}$ & 1.5 & 0.25 & 0.2 & & & & & $\begin{array}{l}\text { ES } \\
\text { LF } \\
\text { SL } \\
\end{array}$ & $\begin{array}{l}48.5 \\
48.5 \\
48.5 \\
\end{array}$ & $\begin{array}{l}68.75 \\
69.23 \\
69.23 \\
\end{array}$ & $\begin{array}{l}12699 \\
12750 \\
12750 \\
\end{array}$ & 48.50 & 69.08 & 12733 & 5.1 \\
\hline & ABD & 1.5 & 0.25 & 0.2 & & & & & $\begin{array}{l}\text { ES } \\
\text { LF } \\
\text { SL } \\
\end{array}$ & $\begin{array}{c}40.75 \\
40.5 \\
40.5 \\
\end{array}$ & $\begin{array}{c}80.57 \\
81.2 \\
81.2 \\
\end{array}$ & $\begin{array}{l}12130 \\
12143 \\
12143 \\
\end{array}$ & 40.58 & 80.99 & 12138 & 20.6 \\
\hline \multirow{3}{*}{$\begin{array}{c}14 \\
\mathrm{~J} 60\end{array}$} & A & 1.5 & 0.25 & 0.2 & & & & & $\begin{array}{l}\text { ES } \\
\text { LF } \\
\text { SL }\end{array}$ & $\begin{array}{l}57.25 \\
57.75 \\
58.25\end{array}$ & $\begin{array}{l}60.89 \\
60.37 \\
59.94\end{array}$ & $\begin{array}{l}14846 \\
14996 \\
15501\end{array}$ & 57.75 & 60.40 & 15114 & 0.0 \\
\hline & $\mathrm{AB}$ & 1.5 & 0.25 & 0.2 & 15 & 13 & 13 & 13 & $\begin{array}{l}\text { ES } \\
\text { LF } \\
\text { SL }\end{array}$ & $\begin{array}{c}56.25 \\
56.75 \\
58\end{array}$ & $\begin{array}{l}62.06 \\
61.44 \\
60.15\end{array}$ & $\begin{array}{l}14679 \\
14767 \\
14855\end{array}$ & 57.00 & 61.22 & 14767 & 1.3 \\
\hline & ABD & 1.5 & 0.25 & 0.2 & & & & & $\begin{array}{l}\text { ES } \\
\text { LF } \\
\text { SL }\end{array}$ & $\begin{array}{c}53.75 \\
53.5 \\
53.5\end{array}$ & $\begin{array}{l}65.11 \\
65.36 \\
65.36\end{array}$ & $\begin{array}{l}14523 \\
14416 \\
14415\end{array}$ & 53.58 & 65.28 & 14451 & 7.2 \\
\hline 15 & $\mathrm{~A}$ & 1.5 & 0.25 & 0.2 & & & & & $\begin{array}{l}\text { ES } \\
\text { LF } \\
\text { SL }\end{array}$ & $\begin{array}{c}53.75 \\
50.25 \\
52.5\end{array}$ & $\begin{array}{l}61.86 \\
66.26 \\
63.96\end{array}$ & $\begin{array}{l}13232 \\
13520 \\
14119\end{array}$ & 52.17 & 64.03 & 13623 & 0.0 \\
\hline $\mathrm{J} 60$ & $\overline{\mathrm{AB}}$ & 1.5 & 0.25 & 0.2 & 13 & 7 & 14 & 14 & $\begin{array}{l}\text { ES } \\
\text { LF } \\
\text { SL }\end{array}$ & $\begin{array}{c}51.25 \\
49 \\
51\end{array}$ & $\begin{array}{l}64.16 \\
67.57 \\
65.41 \\
\end{array}$ & $\begin{array}{l}13015 \\
12843 \\
13041 \\
\end{array}$ & 50.42 & 65.72 & 12966 & 3.4 \\
\hline & $\mathrm{ABD}$ & 1.5 & 0.25 & 0.2 & & & & & $\begin{array}{l}\text { ES } \\
\text { LF } \\
\text { SL } \\
\end{array}$ & $\begin{array}{c}45.5 \\
44.75 \\
45.25 \\
\end{array}$ & $\begin{array}{l}71.86 \\
72.84 \\
72.15 \\
\end{array}$ & $\begin{array}{l}11889 \\
11752 \\
11914 \\
\end{array}$ & 45.17 & 72.29 & 11851 & 13.4 \\
\hline 16 & $\mathrm{~A}$ & 1.8 & 0.5 & 0.5 & & & & & $\begin{array}{l}\text { ES } \\
\text { LF } \\
\text { SL }\end{array}$ & $\begin{array}{c}87.25 \\
90.5 \\
94.25\end{array}$ & $\begin{array}{l}70.44 \\
68.27 \\
65.32\end{array}$ & $\begin{array}{l}37691 \\
39702 \\
40341\end{array}$ & 90.67 & 68.02 & 39244 & 0.0 \\
\hline J60 & $\overline{\mathrm{AB}}$ & 1.8 & 0.5 & 0.5 & 13 & 15 & 11 & 14 & $\begin{array}{l}\text { ES } \\
\text { LF } \\
\text { SL }\end{array}$ & $\begin{array}{c}86.75 \\
89.5 \\
88.75\end{array}$ & $\begin{array}{l}70.93 \\
68.94 \\
69.35 \\
\end{array}$ & $\begin{array}{l}37609 \\
38607 \\
38144\end{array}$ & 88.33 & 69.74 & 38120 & 2.6 \\
\hline & ABD & 1.8 & 0.5 & 0.5 & & & & & $\begin{array}{l}\text { ES } \\
\text { LF } \\
\text { SL } \\
\end{array}$ & $\begin{array}{c}72 \\
74.25 \\
72 \\
\end{array}$ & $\begin{array}{l}85.64 \\
83.49 \\
85.76 \\
\end{array}$ & $\begin{array}{l}33104 \\
33523 \\
32744 \\
\end{array}$ & 72.75 & 84.97 & 33123 & 19.8 \\
\hline 17 & $\mathrm{~A}$ & 1.8 & 0.5 & 0.5 & & & & & $\begin{array}{l}\text { ES } \\
\text { LF } \\
\text { SL } \\
\end{array}$ & $\begin{array}{c}109.5 \\
99.25 \\
101.25 \\
\end{array}$ & $\begin{array}{l}64.28 \\
68.43 \\
67.52 \\
\end{array}$ & $\begin{array}{l}54842 \\
53007 \\
54593 \\
\end{array}$ & 103.33 & 66.75 & 54147 & 0.0 \\
\hline $\mathrm{J} 60$ & $\mathrm{AB}$ & 1.8 & 0.5 & 0.5 & 13 & 15 & 13 & 16 & $\begin{array}{l}\text { ES } \\
\text { LF } \\
\text { SL }\end{array}$ & $\begin{array}{l}99 \\
92 \\
93\end{array}$ & $\begin{array}{l}71.02 \\
73.14 \\
72.58\end{array}$ & $\begin{array}{l}47769 \\
44659 \\
45152\end{array}$ & 94.67 & 72.25 & 45860 & 8.4 \\
\hline & ABD & 1.8 & 0.5 & 0.5 & & & & & $\begin{array}{l}\text { ES } \\
\text { LF } \\
\text { SL }\end{array}$ & $\begin{array}{c}82 \\
80.75 \\
80.75 \\
\end{array}$ & $\begin{array}{l}82.17 \\
83.54 \\
83.54 \\
\end{array}$ & $\begin{array}{l}42080 \\
41564 \\
41578 \\
\end{array}$ & 81.17 & 83.09 & 41740 & 21.5 \\
\hline 18 & $\bar{A}$ & 1.8 & 0.5 & 0.5 & & & & & $\begin{array}{l}\text { ES } \\
\text { LF } \\
\text { SL }\end{array}$ & $\begin{array}{l}91.75 \\
82.75 \\
97.25\end{array}$ & $\begin{array}{l}68.08 \\
75.57 \\
65.02\end{array}$ & $\begin{array}{l}42775 \\
39575 \\
47946\end{array}$ & 90.58 & 69.56 & 43432 & 0.0 \\
\hline $\mathrm{J} 60$ & $\mathrm{AB}$ & 1.8 & 0.5 & 0.5 & 14 & 18 & 14 & 14 & $\begin{array}{l}\text { ES } \\
\text { LF } \\
\text { SL }\end{array}$ & $\begin{array}{c}81 \\
80 \\
83.25\end{array}$ & $\begin{array}{l}77.05 \\
78.06 \\
75.30 \\
\end{array}$ & $\begin{array}{l}36644 \\
36219 \\
36939 \\
\end{array}$ & 81.42 & 76.81 & 36600 & 10.1 \\
\hline & $\mathrm{ABD}$ & 1.8 & 0.5 & 0.5 & & & & & $\begin{array}{l}\text { ES } \\
\text { LF } \\
\text { SL } \\
\end{array}$ & $\begin{array}{c}75 \\
75.75 \\
76.25 \\
\end{array}$ & $\begin{array}{l}83.70 \\
82.80 \\
82.19 \\
\end{array}$ & $\begin{array}{r}34067 \\
34219 \\
34457 \\
\end{array}$ & 75.67 & 82.90 & 34247 & 16.5 \\
\hline 19 & $\mathrm{~A}$ & 1.8 & 0.5 & 0.5 & & & & & $\begin{array}{l}\text { ES } \\
\text { LF } \\
\text { SL }\end{array}$ & $\begin{array}{c}88 \\
81.5 \\
85.25\end{array}$ & $\begin{array}{l}66.12 \\
71.39 \\
68.65\end{array}$ & $\begin{array}{l}36010 \\
36544 \\
36477\end{array}$ & 84.92 & 68.72 & 36343 & 0.0 \\
\hline J60 & $\overline{\mathrm{AB}}$ & 1.8 & 0.5 & 0.5 & 13 & 15 & 15 & 14 & ES & 84.5 & 68.66 & 33838 & & & & \\
\hline & & & & & & & & & $\begin{array}{l}\text { LF } \\
\text { SL }\end{array}$ & $\begin{array}{c}78.25 \\
79.5\end{array}$ & $\begin{array}{l}74.06 \\
73.01 \\
\end{array}$ & $\begin{array}{l}33026 \\
33728 \\
\end{array}$ & 80.75 & 71.91 & 33530.67 & 4.9 \\
\hline & ABD & 1.8 & 0.5 & 0.5 & & & & & $\begin{array}{l}\text { ES } \\
\text { LF }\end{array}$ & $\begin{array}{c}72.25 \\
69.5\end{array}$ & $\begin{array}{l}80.80 \\
83.55\end{array}$ & $\begin{array}{l}29341 \\
29275\end{array}$ & 71.00 & 82.06 & 29211 & 16.4 \\
\hline & & & & & & & & & SL & 71.25 & 81.83 & 29019 & & & & \\
\hline & A & 1.8 & 0.5 & 0.5 & & & & & $\begin{array}{l}\text { ES } \\
\text { LF }\end{array}$ & $\begin{array}{l}79.25 \\
83.25\end{array}$ & $\begin{array}{l}69.75 \\
66.28\end{array}$ & $\begin{array}{l}36981 \\
38430\end{array}$ & 82.17 & 67.25 & 38453 & 0.0 \\
\hline
\end{tabular}




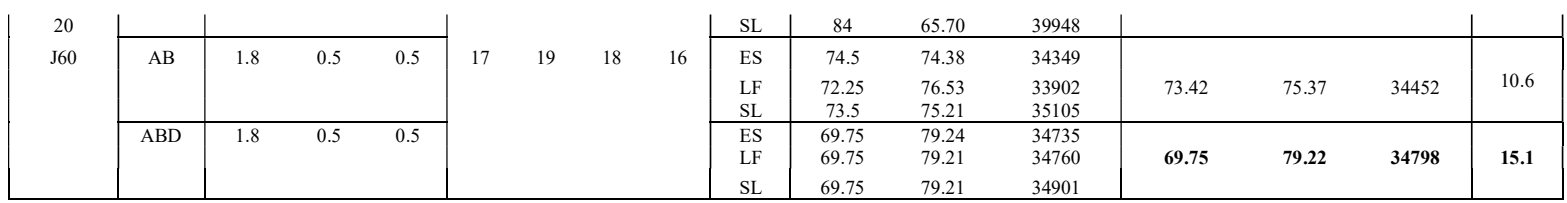

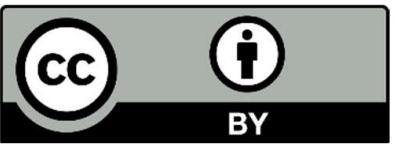

(C) 2020 by the authors; licensee Growing Science, Canada. This is an open access article distributed under the terms and conditions of the Creative Commons Attribution (CC-BY) license (http://creativecommons.org/licenses/by/4.0/). 